\title{
Using Material Authenticity in the Saudi English Textbook Design: A Content Analysis from the Viewpoint of EFL Teachers
}

\author{
Yousif A. Alshumaimeri \\ College of Education, King Saud University \\ PO. box. 44, Marat 11933, Saudi Arabia \\ Maha S. Alzyadi (Corresponding author) \\ College of Education, King Saud University \\ PO. box. 44, Marat 11933, Saudi Arabia \\ E-mail: mahazy1402@gmail.com
}

Doi:10.7575/aiac.alls.v.6n.2p.229

URL: http://dx.doi.org/10.7575/aiac.alls.v.6n.2p. 229
Received: $18 / 12 / 2014$

Accepted: 22/02/2015

\begin{abstract}
This study attempts to identify the extent of using authentic materials in the new series of secondary English textbooks (Flying High for Saudi Arabia) used currently in Saudi schools. Therefore, a content analysis instrument has been designed to analyze the first secondary English textbook. The instrument has been distributed on 112 EFL female teachers who work in public Secondary schools in Riyadh city. The findings show that the selected textbook focuses to a moderate extent on using material authenticity. The provided materials promote genuine communication among EFL learners, prepare learners for the future uses of the target language and present authentic language in its actual contexts. However, the findings reveal that the used materials are beyond the learners' level and the reading comprehension activities present real life texts at a poor range. These findings suggest to adjust the given materials to fulfill the learners' needs and match their proficiency level.
\end{abstract}

Keywords: Authenticity, Authentic materials, Textbook, Communication, Syllabus design

\section{Introduction}

English language in Saudi Arabia is considered a foreign language where Saudi learners lack real opportunities to use English language in their daily life outside the classrooms. In fact, English class is the only place that provides students with opportunities to practice the target language effectively and develop their linguistic skills. To use English language for communicative purposes, learners should be exposed to authentic materials that enable them to use the target language in daily life situations. The use of authentic materials in an EFL classroom has been discussed by EFL teachers recently. There are influential opinions that insisted on presenting authentic materials in EFL classes instead of materials that are only produced for pedagogic purposes. Zohoorian \& Baghban (2011) stressed the importance of using authentic materials to update learners' knowledge and provide an exposure to the real world through using authentic language in EFL classes. In other words, authentic materials present the real life language that is used for communication among native speakers, or in the selected contexts that use Standard English such as newspaper reports, magazine articles, television advertisements, restaurant menus, application forms, etc. Most of the teachers all over the world agree that authentic texts or materials are essential to activate the language learning process.

Since textbooks play an essential role in language classrooms in all types of educational institutions such as schools, colleges, language schools all over the world. Most of the students who use a textbook as their resource feel secure and have a sense of progress and accomplishment. Textbooks can be-a resource for independent learning, an effective source for introducing materials to the teachers, a source of ideas and activities, a reference source for students, a syllabus that reflects preset learning objectives, and a support for novice teachers who lack experience in selecting the efficient language materials. As cited in Tomlinson (2012), Nunan (1999) stated that textbooks can be quite beneficial and a comfort zone for teachers who may feel stressed and overloaded with the extra time and effort needed to prepare for a new lesson. However, most of the English Language textbooks for EFL classes were designed to build the learner's language knowledge (linguistic competence) such as vocabulary and grammar rather than develop his/ her ability to communicate (communicative competence) although the ultimate goal of learning English as foreign language EFL is to enable learners to communicate and use the target in real life situations. According to Alzuhairi (2008), a professional interest has increased in the mid-1980s in using the communicative language teaching approach and designing materials including textbooks that promote real communication among learners. This professional recognition reflects the necessity of using authentic materials that help English teachers to create a communicative environment in their classes and help learners to communicate effectively in the real world using real life language. Tomlinson (2012) 
mentioned that most of the textbook materials that the learners get involved in should be authentic so that learners can be prepared for the future uses of English language in the real world outside the classroom and be able to use the target language for communication.

\subsection{Background}

English language doesn't have an official status in Saudi Arabia except being introduced as a subject in all the three stages of Saudi schools (Elementary, Intermediate and Secondary). Typical people in Saudi Arabia learn English language either because it is a compulsory subject in all stages of Saudi schools or it is one of the requirements to get a certain job. According to Almazloum and Qeshta (2009), introducing English language in the daily life of the nonnative speakers is the responsibility of the educational organization in their countries through designing a curriculum that fulfills the needs and beliefs of a certain country. Teaching English in Saudi public schools starts from the $4^{\text {th }}$ grade in elementary stage where students study English twice a week while English language subject has four periods a week in both intermediate and secondary stages. English language curriculum is designed by local and multinational experts in syllabus design under the supervision of the Ministry of Education (MOD). All over the years, different series of English textbooks have been introduced by the Saudi Ministry of Education for all the three stages of Saudi schools. The current series of textbooks that are taught in Saudi public schools are (Smart Class) for elementary stage, (Wonderful World) for intermediate stage and (Flying High for Saudi Arabia) for Secondary stage.

Since the secondary stage is the last stage for Saudi students to attend before joining universities or other institutions of high education, English curriculum of secondary schools in Saudi Arabia should prepare secondary students for the required proficiency level of English to attend universities. This is one of the general aims of teaching English in the secondary stage in Saudi Arabia that were set by the Saudi Ministry of education (MOD) in 1970, cited in Alshumaimeri (2001):

1. To afford the secondary school pupil a window on the world.

2. To give the secondary school pupil an experience of delight through reading samples of English that have a universal appeal both in arts and sciences.

3. To cultivate the pupil's critical thinking as a useful adjunct to intelligent reading of English texts.

4. To give play to the pupil's imagination by means of imagery in poetry and visualization of character.

5. To provide the pupil who intends to join the university or other higher institutes with an adequate knowledge of English to help him in his future studies.

6. To give the pupil who finishes his formal education in the third year of secondary education sufficient knowledge of the language to help him in his vocation.

Several studies that evaluated English curriculum in Saudi Arabia such as Khinkar (2000) and Alzuhairi (2008) revealed that Saudi secondary students have a low level of language proficiency. The results showed that the used English textbook in secondary stage causes difficulties that affect learners' achievement negatively. As in Alshumaimeri (2003), English teachers mentioned that the graduate students from Saudi secondary school are unable to perform a short conversation in English. The previous series of English textbook. (English for Saudi Arabia) that was taught in Saudi secondary schools for years created a gap between the language used inside the classroom and the authentic language used for communication. According to Mahib urRhaman \& Alhaisoni (2013), the syllabus designers and the educational authorities in Saudi Arabia failed to select an English textbook that respond to the learners' needs. However, the secondary English curriculum was developed recently by the Ministry of Education (MOE) and in 2009, a new series of textbooks for the secondary stage (Flying High for Saudi Arabia) has been taught in Saudi schools since then.

\subsection{The Problem Statement}

Since textbooks are effective resources that help English teachers to activate daily life communication in their classes, English syllabus designers should take into their consideration the necessity of integrating authentic materials within the text-based materials while designing an English textbook. Unfortunately, the previous series of the Saudi English textbook (English for Saudi Arabia) that had been used in Saudi secondary schools for about twelve years didn't focus on using authentic materials as it should be. According to Khinkar (2000), there was a lack of authenticity in text-based materials as they were just simplified materials that focused mostly on grammar and vocabulary rather than promoting the use of target language for communicative purposes. Many attempts have been made by the English Language Development Project (ELDP) to produce a new series of English textbook. However, most of these attempts ignored the importance of integrating authentic materials within the content of the textbook and focused mostly on providing language knowledge among secondary students rather than providing intensive practices of the language for communication. This was one of the major difficulties that the researcher of this study had been through while teaching English for secondary grade. The previous series of the Saudi English textbook (English for Saudi Arabia) was replaced in 2009 with a new series (Flying High for Saudi Arabia) in which its designers claim that the new textbook is basically designed to provide authentic situations to the learners that help them to reinforce using the target language communicatively.

\subsection{The Significance of the Study}

In this study, the content of the new textbook (Flying High for Saudi Arabia) has been analyzed from the viewpoint of secondary EFL teachers all over Riyadh city to investigate whether the provided materials in the textbook can be considered authentic. In the same time, this study aims to identify the role that these materials play in activating the 
learners' communicative skills on authentic topics related to their real life. It makes an emphasis on the necessity of using authentic materials in a textbook due to its importance in creating a communicative environment in English classes. This study focuses on the use of authentic materials in secondary English textbook because students at secondary grade should be prepared for attending a university. So, they need materials that strengthen their language skills and reflect language practices for real-life purposes, especially students who want to study abroad should get intensive practices that enable them to deal with any situation in their real lives. The results of this study can be quiet beneficial for both syllabus designers in Saudi Arabia and English teachers all over Saudi Arabia. Results can show syllabus designers whether the provided materials of the current textbook can promote communication among Saudi learners and prepare them to the real world outside classrooms or not. In addition, they revealed the extent that the selected materials can help teachers to create a communicative environment in their classes and what flaws the available materials have and what changes should be made to make these materials more authentic. Moreover, the results can help English teachers to be more aware of the provided materials of the current textbook and what these material lack and what these material need to activate them as effective resources in their classes.

\subsection{The Purpose of the Study}

The purpose of the study is to study, analyse and describe the selected materials that are used as a content of the new English textbook in Saudi schools. This study attempts to identify the extent that the new series of the Saudi English textbook (Flying High for Saudi Arabia) focuses on using authentic materials that promote communication among Saudi learners through exposing them to daily life situations. It investigates whether this new series succeed in connecting learners with future uses of English language outside the classroom and building a background knowledge for Saudi learners through introducing them to new ideas and content from real-life. This study particularly attempts to answer the following questions:

1. To what extent do the objectives of 1st Secondary textbook - (Flying High for Saudi Arabia) focus on materials authenticity?

2. To what extent does the content of the 1st Secondary textbook - (Flying High for Saudi Arabia) in the mid1980s.focus on materials authenticity?

3. To what extent do the activities of the 1st Secondary textbook - (Flying High for Saudi Arabia) focus on materials authenticity?

\section{Literature Review}

\subsection{The Significance of Textbooks}

For decades, there has been an argument about whether textbook can be considered the ideal medium for presenting language learning materials. Allwright (1981) cited in Berardo (2006) began a debate in 1981 as he built arguments against textbooks' ways in introducing language learning materials. On the other hand, O'Neil (1982) cited in Tomlinson (2012) was strongly defending textbook essential role in delivering language-learning materials. From that time, several academics contributed in this debate such as Prabhu (1989), Littlejohn (1992), Hutchinson \& Torres (1994), Wajnryb (1996)), Thornbury \& Meddings (2001), Gray (2002), Mishan (2005), Dat (2006) and Mukundan (2009) as cited in Tomlinson (2010).

Although educational experts have been against using textbook as the medium to deliver language learning materials, language teachers all over the world believe in the importance of using textbooks as the main source for delivering language materials in their classes and continue to use them regardless of what the experts' criticism. For example, a survey that has been conducted by the British Council (2008) showed that $65 \%$ of the teachers usually or regularly used a textbook and only $6 \%$ never did. Another survey at conferences in Malaysia, the United Kingdom and Vietnam, Tomlinson (2010) revealed that the majority of the participants used a textbook frequently because it was one of the requirements. On the other hand, $78 \%$ of the participants showed some negativity about the textbooks that were provided to them. Supporters of the textbook claim that it is a cost-effective way to the learner that provides security, organization, development and revision. At the same time, using textbooks saves their saving time and supports EFL teachers with the resources that work as basis to their lessons and enrich them. Moreover, it motivates supervisors to accomplish course reliability, timetable lessons and high standards teaching.

Opponents of textbooks argued that coursebook can have negative effects for both teacher and learners, Mukundan (2009) claimed that they cannot fulfil the learners' needs and match their interest, they are used mainly to enforce control, order and only deliver a delusion of system and progress. A lot also claimed that a textbook has shallow coverage of the language features and superficial in its delivery of language experience. Tomlinson (2001) mentioned that textbook imposes the homogeneity of syllabus and method, and it eliminates EFL teachers' creativity and power. Furthermore, it has been claimed that textbooks are designed with a lot of authority which can be challenging for teachers or learners to change or adjust them (Luke, de Castell \& Luke 1989; Dendrinos 1992) cited in Tomlinson (2010). However, Apple (1992), Hutchinson \& Torres (1994) cited in Tatsuki (2006) mentioned that such changes do occur. Tomlinson (2010) put forward another argument against textbooks claiming that they are designed mainly to satisfy supervisors and teachers but in the same times, usually neglect the learners' needs and interests.

Tomlinson's view (2012) was that textbooks are necessary to save time, effort and money and a lot of EFL teachers want a coursebook as a basic source that provides them with everything they need. He believed that a textbook can do what its proponents have claimed. However, number of international textbooks don't fulfil the learners actual needs and 
are not related to their real world. Trying to satisfy for all students at a particular age and level, global coursebooks often failed in matching the learners' interests and needs. Gilmore (2007) stressed that international textbooks should be flexible and provide teachers and students with real opportunities to choose materials that suit their personal preference and local context. Furthermore, publishers could produce online global 'coursebooks' that provide opportunities to select, adjust and change language materials. This can support a constant process where materials are developed and accordingly reformed through the whole process.

\subsection{Authenticity of Texts and Tasks}

Most typical textbooks provide language teaching explicitly via using artificial samples and texts that make learners concentrate mainly on the given language feature in unnatural context. This issue has been argued by a lot of SLL researchers who claimed that most textbooks usually make learners overprotected that prevents them from being prepared for the future uses of the target language in the real world. Researchers like Bacon \& Finneman (1990), McGarry (1995), Wong, Kwok \& Choi (1995), Nuttall (1996) cited in Mishan (2005) and Rilling \& Dantas-Whitney (2009) claimed that authentic materials can offer new knowledge, significant exposure to the target language like it is used in an actual context, improve learners' communicative abilities, increase their motivation and develop their attitudes positively to learn the target language. Duquette, Dunnett, \& Papalia, (1989) cited in Mousavi (2012) mentioned that listening to authentic aural texts can develop the learners' linguistic abilities. Moreover, Guariento \& Morley (2001) mentioned that introducing new knowledge and new changes that occur in the uses of English language through authentic materials can motivate students to learn the language in the classroom as they realize that it can be used in real life. Trabelsi (2010) put forwards arguments for providing learners with authentic materials because they are customized to the learners' needs and are appropriate to the syllabus designers' expectations and demands.

Several academics such as Gilmore (2004) made a comparison between authentic materials with text-based materials in typical textbooks. They noticed that textbooks that are used currently lack authenticity which is considered one major flaw of the textbooks. On the other hand, other academics, such as Widdowson $(1984,2000) \&$ Ellis (1999) cited in Tomlinson (2012) and Day (2003) argued that authentic materials can cause numerous problems for learners; they discussed the necessity of creating materials that can simplify language learning. For instance, Widdowson (1984) cited in Shomoossi \& Ketabi (2007) stated that to introduce foreign language in pedagogic form, language features should be isolated from their natural contexts and Day (2003) opposed fiercely supporters of authenticity, claiming that there is no practical evidence that shows authenticity role in facilitating language learning, but there is a clear evidence that authentic texts are more difficult for EFL learners than simplified texts.

Prodromou (1992) cited in Trabelsi (2010) discussed how authenticity is related to the learners' culture. What can be considered authentic for one country (or even for one learner) cannot be considered authentic for another. What makes a material authentic is the learner's interaction with it and not the type of text or the task. Widdowson (1978), as cited in Shomoossi \& Ketabi (2007), differentiated between how genuine a text is and how authentic its use is, Breen (1985) in Tomlinson (2012) made an emphasis on the authenticity of the learner's own understanding and the social contexts in their classroom and Van Lier (1996) cited in Tomlinson (2012) pointed out that authenticity is essentially "a personal process of engagement". According to Tomlinson (2012), an authentic text is used for communicative purposes rather than to be used as instructional materials, and an authentic task is designed to engage the learners in real interaction to accomplish an outcome, more than to practice the target language.

Amrani (2011) believed that texts that are selected for textbooks might not be produced by native speakers but it can be a simplified version of the original texts to simplify communication. He stresses that there is no need for real-life task, and can be replaced by a classroom task that promotes the use of communicative skills in real life situations to accomplish not only active communication but other non-linguistic outcomes. Tomlison (2012) stated that most of the texts and tasks that learners get involved in should be authentic to prepare learners for the future uses of the target language in the real world outside the classroom and enable them to use the target language in daily life situations.

\subsection{Authentic Materials vs. Text-based Materials}

Velazquez (2007) stated that EFL teachers usually apply two types of texts for teaching which are either authentic or simplified. According to Velazquez, both types of texts are important. He preferred simplified texts compared to authentic texts because the language of simplified texts is easy to comprehend which is adapted to students' language proficiency level. He claimed that simplified texts can strengthen vocabulary and grammar and prepare learners for reading authentic texts. Tomlinson (2001) mentioned that since the artificial materials focus on the target language form they can be more beneficial to learners although he admitted later that if meaningful exposure to language is the purpose, authentic materials is the right choice to use. Authentic materials are important because they contain cultural aspects and show the learner how native speakers use the target language in every aspect of their lives..

Text-based materials are valuable because they use more familiar structures and forms. These are more appropriate when a new grammatical structure is to be introduced. However, there are some disadvantages of text-based materials as Horwitz (2008) stated e.g. being less interesting and lacking opportunities of real exposure to the target language. She also mentioned that both authentic and constructed materials are important to be used for intensive reading while for extensive reading authentic materials are more beneficial. Concerning textbook materials, Shrum and Glisan (2000) stated that although many language textbooks contain a variety of grammatical structures, they contain less interesting and illogically sequenced texts and dialogues that do not represent real-life language or situations. 
Different scholars described how to choose materials that can help learners in learning languages. One of the valuable suggestions, as Zohoorian \& Baghban (2011) mentioned, is using authentic materials because they can support learners with up to-date knowledge, provide a real exposure to the world of authentic target language and bring the real world into the classroom,...etc. Authentic materials can motivate students and stimulate them to learn the target language. The majority of the studies that the researcher reviewed concerning using authentic materials in English classes addressed authentic materials separately from text-based materials. However, the researcher thinks that both materials should be included in the designed textbook with a focus on the use of authentic materials. Using authentic materials enable EFL learners to apply the language practices in the classes in their daily life situations. Since language textbook has an essential role in delivering language learning material and facilitating language learning, It can be a beneficial source for both teachers and students that provides basic practices of authentic language in EFL classes to serve communicative purposes. The researcher is interested to identify if the current secondary English textbooks in Saudi Arabia promote communication among Saudi learners. Therefore, this study is conducted to investigate the extent of using authentic materials in English textbook design in the current series of secondary English textbook-Flying High for Saudi Arabia-level 1.

\section{Methodology}

\subsection{Research Method}

The researcher used the descriptive analytic method depending on content analysis. According to Sandelowski (2000), descriptive method not only describes a certain phenomenon but also collects, arranges and categorizes the data about this phenomenon quantitatively that leads to a better understanding of the relationships between this phenomenon and other phenomena. Arranging and categorizing collected data aim to reach certain conclusions that help in developing the reality that the researcher studies.

\subsection{First Study Population \& Sample}

Since content analysis is the selected tool for this research, English textbook (Flying High for Saudi Arabia-level1) that is taught in public schools in Saudi Arabia represents the first population of this research and all the unites of this textbook represent the participants of this research. Therefore, the population of this research is the same as the participants.

\subsection{Second Study Population \& Participants}

As the analysis process of the textbook content has been conducted by 1st secondary English teachers who are the real practitioners of the selected textbook since they usually use it in their classes. Therefore, the second participants in this study are (112) secondary EFL female teachers selected out of (593) Secondary English language teachers working in (189) public Secondary school in Riyadh to be the purposeful sample in this study. The second population is all Secondary English language teachers working in public secondary schools in Riyadh with a total number of (593) teachers. This number is estimated by the data collection center in the Saudi Ministry of Education. So, the population of this study is well represented by the selected participants.

\subsection{Data Collection Tool}

The researcher built a content analysis instrument as data collection tool for this study after reviewing the related studies to the research topic. Krippendorff (1980) cited in Wilkinson \& Birmingham (2003) described content analysis as an effective research tool that is used to collect and analyze data to make credible presumptions that can be replicated to their contexts. The designed content analysis instrument has collected the needed data to form a complete background about the issue. This instrument consists of three major dimensions which are Textbook Objectives, Textbook Content and Textbook Activities. Each dimension consists of a number of items that investigates certain the availability of certain elements related to their dimension.

\subsubsection{Analysis Unit}

The analysis unit that was chosen by the analyzers is represented in a page i.e. the analyzers analyzed all the pages of the selected textbook to find out how available the standards are on each page.

\subsubsection{Analysis Categories}

The researcher set a 1-3 scale (Available-Available at some point-Unavailable) to estimate the degree of availability for each item of the designed content analysis instrument.

\subsubsection{Reliability}

To measure how reliable the content analysis is, a Pilot Study is conducted by selecting a sample of 30 participants of 1st secondary English teachers in Riyadh who participated in analyzing the selected English textbook (Flying High for Saudi Arabia- level 1) twice. They analyzed the textbook for the first time using the designed instrument and after a month they repeated the analysis process using the same content analysis instrument for the second time. The reliability coefficient of the analysis in both attempts has been calculated by using (Cooper's Equation) that reveals the percentage of agreements of all analyzers in both attempts. 


\section{Cooper's coefficient}

[No. agreements $\div$ (No. of agreements + No. of disagreements)] $\times 100$

Cooper's coefficient that has been calculated by the researcher shows a high percentage of agreements of all analyzers in both attempts that is $90 \%$, as it is shown in the tables (1) below:

Table 1. Cooper's Coefficient of the Content Analysis Instrument's Dimensions

\begin{tabular}{cc}
\hline $89 \%$ & First Dimension \\
\hline $90 \%$ & Second Dimension \\
\hline $91 \%$ & Third Dimension \\
\hline $90 \%$ & Cooper coefficient \\
\hline
\end{tabular}

The percentage of the analyzers 'agreement in both attempts is a high percentage which refers to the reliability of the content analysis instrument.

\subsection{Data analysis}

Descriptive statistics have been used such as Percentages (\%) and Frequencies (F) as basic data analysis techniques to analyze the collected data statistically in SPSS 16.0. The analyzed data and the obtain findings are illustrated in number of tables and figures of the percentages $(\%)$ and frequencies $(F)$ that show the availability degree of each item in the instrument.

\section{Results of the Study}

\subsection{Data Analysis of the First Dimension (Textbook Objectives)}

Table 2. Frequencies \& Percentages of the First Dimension (Textbook Objectives)

\begin{tabular}{|c|c|c|c|c|c|c|c|}
\hline & \multirow[t]{2}{*}{ Objectives } & \multicolumn{2}{|c|}{ Available } & \multicolumn{2}{|c|}{$\begin{array}{c}\text { Available } \\
\text { at some point }\end{array}$} & \multicolumn{2}{|c|}{ Unavailable } \\
\hline & & $\mathrm{F}$ & $\%$ & $\mathrm{~F}$ & $\%$ & $\mathrm{~F}$ & $\%$ \\
\hline 1 & $\begin{array}{l}\text { Using real life language for } \\
\text { communication. }\end{array}$ & 90 & $80 \%$ & 18 & $16 \%$ & 4 & $4 \%$ \\
\hline 2 & $\begin{array}{l}\text { Practicing English language for } \\
\text { communicative purposes. }\end{array}$ & 81 & $72 \%$ & 27 & $24 \%$ & 4 & $4 \%$ \\
\hline 3 & $\begin{array}{l}\text { Using authentic materials that reflect } \\
\text { the learners' culture. }\end{array}$ & 65 & $58 \%$ & 43 & $38 \%$ & 4 & $4 \%$ \\
\hline 4 & $\begin{array}{l}\text { Activating the learners' skills on } \\
\text { authentic topics. }\end{array}$ & 46 & $41 \%$ & 62 & $55 \%$ & 4 & $4 \%$ \\
\hline 5 & $\begin{array}{l}\text { Connecting learners with future uses of } \\
\text { English language. }\end{array}$ & 81 & $72 \%$ & 27 & $24 \%$ & 4 & $4 \%$ \\
\hline 6 & $\begin{array}{l}\text { Preparing learners to use English in } \\
\text { their real lives. }\end{array}$ & 41 & $37 \%$ & 66 & $58 \%$ & 5 & $5 \%$ \\
\hline 7 & $\begin{array}{l}\text { Presenting authentic language } \\
\text { through the used materials. }\end{array}$ & 87 & $78 \%$ & 25 & $22 \%$ & 3 & $3 \%$ \\
\hline 8 & $\begin{array}{l}\text { Introducing speech in socio-cultural } \\
\text { context. }\end{array}$ & 30 & $27 \%$ & 75 & $67 \%$ & 7 & $6 \%$ \\
\hline 9 & $\begin{array}{l}\text { Building up to date knowledge } \\
\text { drawn from real life. }\end{array}$ & 83 & $74 \%$ & 24 & $21 \%$ & 5 & $5 \%$ \\
\hline
\end{tabular}

Findings in table 2 show that in item (1), 80\% of the analyzers agree that textbook objectives make a noticeable emphasis on practicing authentic language to promote communication in EFL classes. In item (2), the textbook objectives focus mainly, about $72 \%$, on providing opportunities for Saudi learners to practice the target language intensively for communicative purposes. In item (3), the textbook objectives are interested to moderate extent, about $58 \%$, on using authentic materials related to the learners' culture. In item (4), the textbook objectives focus to a moderate extent, about $55 \%$, on activating learners' communicative skills on authentic topics related to their real life.

In item (5), the textbook objectives focus to a large extent, about $72 \%$, on connecting Saudi learners with future uses of the target language outside classroom. In item (6), the textbook objectives focus to moderate extent on, about 58\%, preparing learners to use English language to deal with any life situation. In item (7), about 78\% of the analyzers agreed textbook objectives focus mainly on language authenticity that is presented through the selected authentic materials. In item (8), 67\% of the participants agreed that textbook objectives aim to moderate extent on introducing a meaningful communication to the learners through socio-cultural context. In item (9), that textbook objectives clearly focus about $74 \%$ on building a up to date knowledge for the Saudi learners through introducing them to new ideas drawn from their real life. 
Table 3. Frequencies \& Percentages of Second Dimension (Textbook Content)

\begin{tabular}{|c|c|c|c|c|c|c|c|}
\hline & \multirow{2}{*}{ Item } & \multicolumn{2}{|c|}{ Available } & \multicolumn{2}{|c|}{$\begin{array}{l}\text { Available } \\
\text { at some point }\end{array}$} & \multicolumn{2}{|c|}{ Unavailable } \\
\hline & & $\mathrm{F}$ & $\%$ & $\mathrm{~F}$ & $\%$ & $\mathrm{~F}$ & $\%$ \\
\hline 1 & $\begin{array}{l}\text { Providing oral materials used by } \\
\text { native speakers. }\end{array}$ & 59 & $53 \%$ & 49 & $45 \%$ & 4 & $4 \%$ \\
\hline 2 & $\begin{array}{l}\text { Helping learners to comprehend native } \\
\text { speakers' speech. }\end{array}$ & 58 & $52 \%$ & 50 & $45 \%$ & 4 & $4 \%$ \\
\hline 3 & $\begin{array}{l}\text { Providing aural materials to develop } \\
\text { listening skill. }\end{array}$ & 83 & $74 \%$ & 25 & $22 \%$ & 4 & $4 \%$ \\
\hline 5 & $\begin{array}{l}\text { Exposing learners to real lite language } \\
\text { in the selected texts. } \\
\text { Providing authentic materials such }\end{array}$ & 33 & $30 \%$ & 75 & $67 \%$ & 4 & $4 \%$ \\
\hline 6 & as newspapers, ..etc. & 69 & $62 \%$ & 42 & $38 \%$ & 1 & $0.9 \%$ \\
\hline 7 & $\begin{array}{l}\text { The reading texts reflect the } \\
\text { learners' real-life purposes. }\end{array}$ & 27 & $24 \%$ & 81 & $72 \%$ & 4 & $4 \%$ \\
\hline 8 & $\begin{array}{l}\text { Presenting topics related to the } \\
\text { learners' culture. }\end{array}$ & 82 & $73 \%$ & 30 & $27 \%$ & 0 & $0 \%$ \\
\hline
\end{tabular}

The findings in table (3) reveal that in item (1), about 53\% of the analyzers agree that oral conversation used in daily situations by native speakers of the language is available to a large extent in the selected textbook. In item (2) 52\% of the participants in the analysis process agree that the selected textbook helps to a large extent Saudi learners to comprehend native speakers in various kinds of speech situations. In item (3), 74\% of the analyzers agree that aural authentic materials that help in developing learners' listening comprehension skill are obviously available in the selected textbook. In item (4), about $59 \%$ of the participants in the analysis process agree that authentic materials used in the selected textbook do not match the learners' language proficiency level. In item (5), 67\% of the participants agree that the selected textbook's texts allow learners to moderate extent to experience the language as it is used for real communication among native speakers. In item (6), 62\% of the analyzers agree that authentic materials such as newspapers, magazines, menus, forms and television advertisements are available to a large extent in the selected textbook. In item (7), 72\% of the participants agree that the reading texts provided in the selected textbook (FHFSA) reflect to a moderate extent the learners' real-life purposes. In item (8), 73\% of the participants agree that the selected textbook indicates appropriate use of visuals and topics related to the Saudi learners' culture. In item (9), 78\% of the analyzers agree that the reading texts of the selected textbook introduce to a moderate extent issues and experiences that Saudi secondary learners have in common.

\subsection{Data Analysis of Third Dimension (Textbook Activities)}

Table 4. Frequencies \& Percentages of the Third Dimension (Textbook Activities)

\begin{tabular}{|c|c|c|c|c|c|c|c|}
\hline & \multirow[t]{2}{*}{ Item } & \multicolumn{2}{|c|}{ Available } & \multicolumn{2}{|c|}{$\begin{array}{l}\text { Available } \\
\text { at some point }\end{array}$} & \multicolumn{2}{|c|}{ Unavailable } \\
\hline & & $\mathrm{F}$ & $\%$ & $\mathrm{~F}$ & $\%$ & $\mathrm{~F}$ & $\%$ \\
\hline 1 & $\begin{array}{l}\text { Activities that present real life } \\
\text { listening contexts. }\end{array}$ & 56 & $50 \%$ & 53 & $47 \%$ & 3 & $3 \%$ \\
\hline 2 & $\begin{array}{l}\text { The listening activities provide } \\
\text { authentic materials. }\end{array}$ & 55 & $51 \%$ & 53 & $47 \%$ & 4 & $4 \%$ \\
\hline 3 & $\begin{array}{l}\text { The speaking activities provide } \\
\text { authentic speech. }\end{array}$ & 28 & $25 \%$ & 79 & $71 \%$ & 5 & $5 \%$ \\
\hline 4 & $\begin{array}{l}\text { The writing activities are drawn from } \\
\text { the learners' lives. }\end{array}$ & 86 & $61 \%$ & 38 & $34 \%$ & 6 & $5 \%$ \\
\hline 5 & $\begin{array}{l}\text { The reading activities serve real life } \\
\text { purposes. }\end{array}$ & 16 & $14 \%$ & 28 & $25 \%$ & 68 & $61 \%$ \\
\hline 6 & $\begin{array}{l}\text { Activities provide practices of } \\
\text { authentic language }\end{array}$ & 38 & $34 \%$ & 69 & $62 \%$ & 5 & $5 \%$ \\
\hline 7 & $\begin{array}{l}\text { Activities introduce topics about } \\
\text { national events. } \\
\text { authentic activities respond to the }\end{array}$ & 24 & $22 \%$ & 80 & $71 \%$ & 8 & $7 \%$ \\
\hline 8 & individual needs. & 5 & $5 \%$ & 49 & $36 \%$ & 67 & $60 \%$ \\
\hline 9 & $\begin{array}{l}\text { Activities present kinds of writing } \\
\text { used in real life. }\end{array}$ & 60 & $54 \%$ & 49 & $44 \%$ & 3 & $3 \%$ \\
\hline 10 & $\begin{array}{l}\text { Activities support learners' } \\
\text { transition into the real world. }\end{array}$ & 68 & $61 \%$ & 41 & $37 \%$ & 3 & $3 \%$ \\
\hline
\end{tabular}


As could be seen in table (4), item (1) shows that $50 \%$ of the analyzers agree that the selected textbook includes to a large extent of activities that introduce real life listening contexts for the learners. In item (2), about $51 \%$ of the analyzers agree that the textbook listening comprehension activities include, to a large extent, authentic materials that help in implementing listening comprehension training for Saudi learners. In item (3), $71 \%$ of the participants in the analysis process agree that the speaking activities in the selected textbook provide exposure to authentic speech to a moderate extent. In item (4), $61 \%$ of the participants in the analysis process agree that the selected textbook provides to a large extent writing activities and materials that are drawn from the learners' lives outside school. In item (5), about $61 \%$ of the analyzers agree that reading activities that serve real life purposes are available at a poor extent in the selected textbook.

In item (6), $62 \%$ of the participants agree that the selected textbook activities provide to a moderate extent intensive practices to prepare students use the language outside the classroom. In item (7), 71\% of the participants agree the activities of the selected textbook introduce to a moderate extent topics about current local and national events in Saudi Arabia. In item (8), about $60 \%$ of the analyzers agree that the authentic activities available in the textbook don't respond to the Saudi learners' individual needs. In item (9), about $54 \%$ of the analyzers agree that the writing activities in the selected textbook provide different kinds of writings related to the learners' real life. In item (10), $61 \%$ of the participants in the analysis process agree that the selected textbook activities support to a large extent learners' transition and integration into the world outside the classroom.

\section{Discussion of the Results}

\subsection{Textbook's Objectives}

Results of the first dimension in table 2, revealed the extent that objectives of the textbook focus on using authentic materials. There are three significant results that show a high percentage of agreement from the participants concerning the use of authentic materials in the selected textbook (FHFSA).

One of the most significant results show that textbook's objectives aim to connect Saudi learners with the future uses of English language. This reflects the syllabus designers' vision of building an efficient English textbook that exposes learners to the various uses of English language that they may need in the future. Tomlinson (2012) stressed that most of the EFL materials that learners get involved in should be authentic to prepare learners for the future uses of the target language in the real world outside the classroom. This objective reveals the syllabus designers' expectations from the authentic materials in this textbook to prepare learners to use English to deal with the upcoming situations in their real lives such as attending a university, doing interviews for a job, studying abroad...etc.

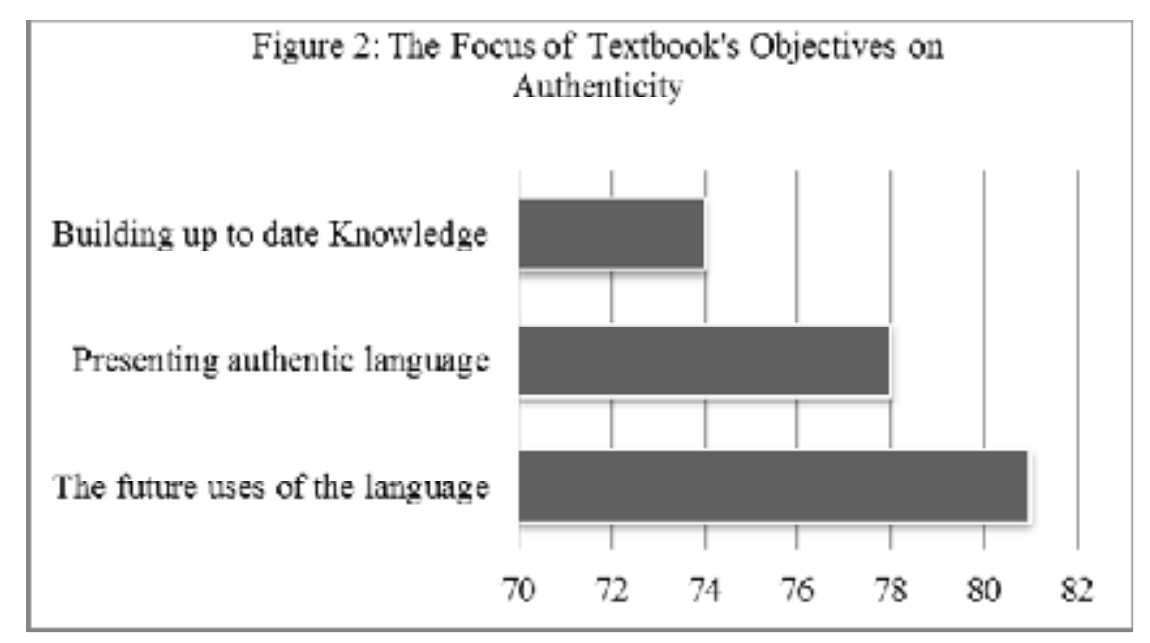

Another important result reveals that one of the objectives of the textbook (FHFSA) is to enable Saudi learners use authentic English language that helps them to communicate effectively in the real world. This refers to the fact that the syllabus designers expect from the authentic materials used in the textbook to present real life language such as common appropriate expressions used by native speakers, appropriate idioms, daily life conversations,...etc. Trabelsi (2010) mentioned that using authentic materials can lead EFL learners to produce a natural talk. Moreover, using authentic language helps to minimize the gap between the language used inside the classroom and the language used by native speakers in real life. In addition, it provides opportunities for students to practice English language for communicative purposes.

The results show that one of the objectives to build up to date knowledge through exposing learners to new ideas and content from real life. This indicates that the used materials in the selected textbook (FHFSA) are full of new concepts drawn from the changes that occur constantly in real life. This refers to the syllabus designers expectations of the authentic materials used in the selected textbook to contribute in refreshing, enriching the learners' background knowledge with new life experiences and keeping them up to date with the changes and new events that happen in life. Zohoorian \& Baghban (2011) stated that it is important to use authentic materials because they can support learners with a new knowledge. 
According to Guariento \& Morley (2001), introducing new knowledge and new changes that occur in the uses of the target language through authentic materials can motivate learners to learn the language in the classroom as they realize that it can be used in real life. This is one of the expected outcomes of using authentic materials in English textbook. Researchers like Bacon \& Finneman (1990), McGarry (1995), Wong, Kwok \& Choi (1995), Nuttall (1996) cited in Mishan (2005) and Rilling \& Dantas-Whitney (2009) stated that authentic materials can offer up to date knowledge, significant exposure to the target language like it is used in an actual context, improve learners' communicative abilities, increase their motivation and develop their attitudes positively to learn the target language.

\subsection{Textbook's Content}

Results in table 3 identify the extent that the content of the selected textbook (FHFSA) focuses on using authentic materials. The results show some remarkable results that show a high percentage of agreement from the participants concerning the availability of authentic materials in the textbook.

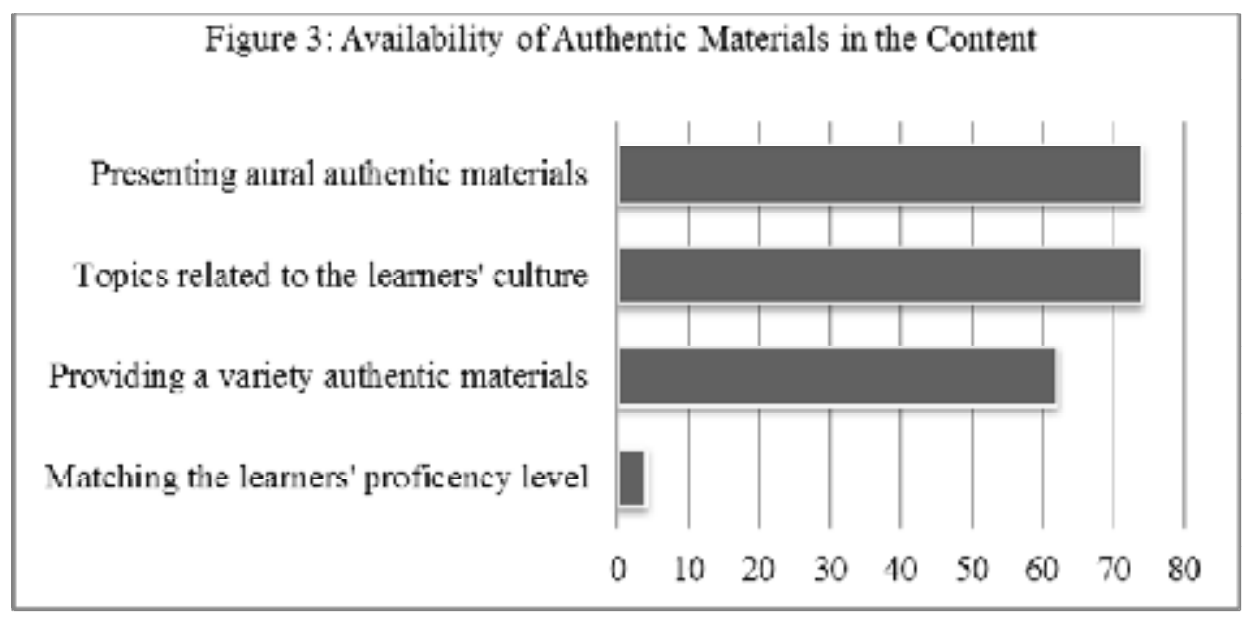

The results reveal that the content of the textbook (FHFSA) contains a variety of authentic aural materials that contribute in implementing intensive listening comprehension training. The selected textbook is supplied with officially approved CDs that contain a variety of aural materials drawn from real life. These materials help Saudi learners to comprehend native speakers speech and their daily life conversation. Breen (1985), as it is cited in Tomlinson (2012), mentioned that providing authentic speech in the listening comprehension practices in EFL classes creates genuine communication and enables learners to have "immediate and direct contact" with the given data. The provided CDs are full of authentic materials like radio interviews, forecast weather, conversation about ordering a meal in a restaurant, booking a room in a hotel, ...etc that help in developing the learners' listening comprehension skill. Duquette,et al, (1989), cited in Mousavi (2012) mentioned that learners who listen to authentic texts develop their linguistic abilities.

One of the remarkable results shows that the various authentic materials available in the selected textbook are beyond their learners' language proficiency level. This can reflect Spelleri's view (2002) and Hwang (2005) who pointed out that the selected materials must be somehow beyond the learners' level to increase their motivation, awareness, and curiosity. However, this can cause major difficulties for those learners in comprehending these materials. The difficulty of authentic materials comes from the fact that these materials are not especially designed for instructional purposes, they are variety of materials that are found in its actual contexts and used by native speakers. Day (2003) mentioned that there is a clear evidence that authentic materials are difficult for EFL learners to used since they are not designed to serve pedagogic purposes. Widdowson $(1984,2000)$ \& Ellis (1999) cited in Tomlinson (2012) and Day (2003) argued that authentic materials can cause numerous problems for learners; they discussed the necessity of creating materials that can simplify language learning. Fei and Yu-feng (2008) mentioned that the learners' level is an important factor while selecting authentic materials as they should be appropriate to their level. Therefore, these materials should be modified to match EFL learners' proficiency level in a way that can't affect their authenticity and facilitate language learning in the same time.

One of the significant results that identifies the extent of using authentic materials in the content reveals that the selected textbook (FHFSA) provides a variety of materials that are considered the main sources of authentic language such as newspapers, magazines, menus, application forms, bills,..etc. Since these materials are usually used by native speakers in their real life, they present the genuine language as it is used by native speakers in its actual context. Using such materials gives EFL learners a real exposure to the target language as it enables them to experience similar situations and practice different kinds of conversations. Kilickaya (2004) mentioned that the feature that most authentic materials have in common is the exposure to real language and its use in the real world outside the classroom. These materials help in developing the learners' communicative abilities. On the other hand, they can be beneficial to EFL teachers as they save their time and efforts especially novices teachers who lack experience of the good sources of EFL materials that promote communication in their classes. 
The findings show that that the selected textbook (FHFSA) provides to wide range appropriate use of visuals that respect the cultural values of the Saudi society. In addition, it deals with authentic topics related to the learners' culture such as their customs, traditions and social believes that help EFL learners to express themselves and know how to introduce their culture to foreigners using the target language. Fei \& Yu-feng (2008) stressed that authentic materials must reflect the social values and attitudes of the learners' society. Also, a cultural and socio linguistic awareness for the learners. Trabelsi (2010) illustrated that authenticity is related to the learners' culture, what can be considered authentic for one country (or even for one learner) cannot be considered authentic for another. Relating authentic materials to the learners' culture makes the learners feel more connected to learn language and more confident to use the target language in their real life.

\subsection{Textbook's Activities}

Results in table (4) reveal the extent that textbook's activities focus on material and language authenticity. Some significant results show a high percentage of agreement from the participants in the analysis process concerning the availability of authentic activities in the selected textbook (FHFSA).

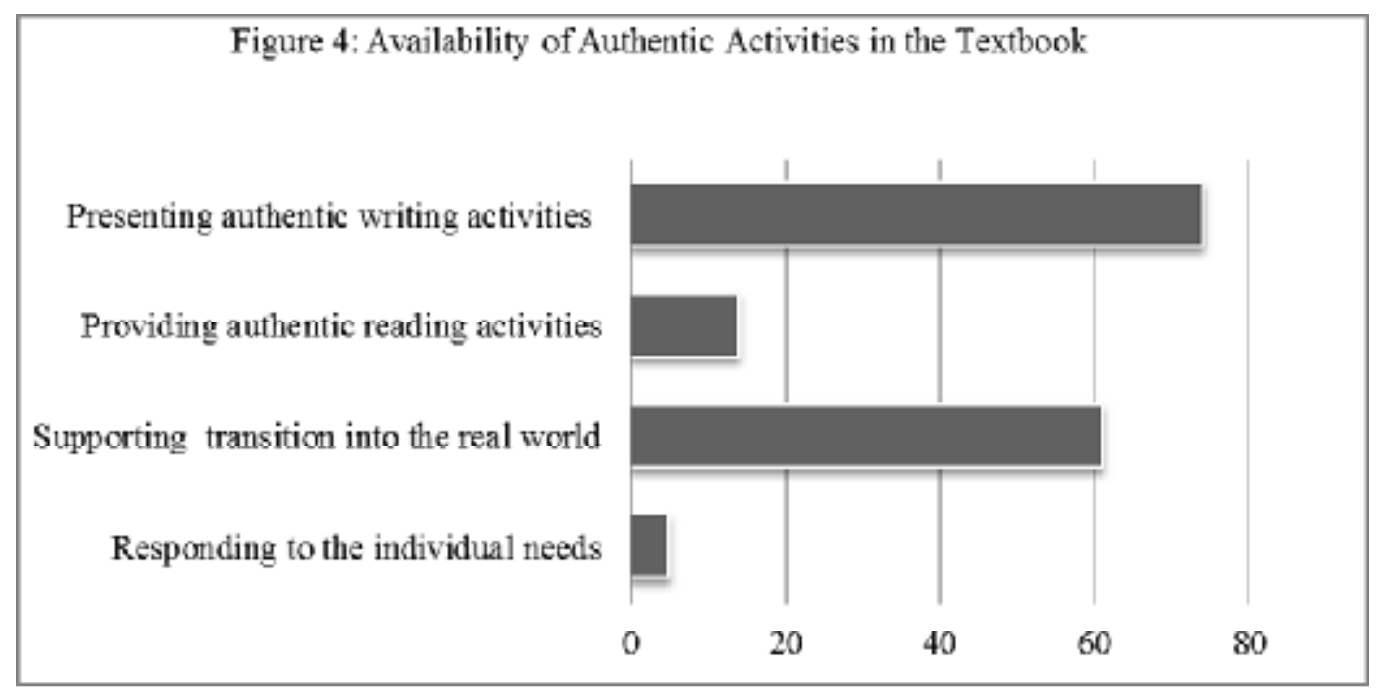

An important result reveals that the provided writing activities in the textbook (FHFSA) reflect the various types of writing that are used for communication in real life such as writing a letter, an e-mail, filling application form, post cards, memo,...etc. Exposing learners to a variety of writing materials provides efficient practices to enhance their writing skills and expands their knowledge of how to write formal and informal types of writings. Authenticity of writing activities increases the learners' motivation to write in the target language and express themselves through their writings such as writing their dairies. Rilling \& Dantas-Whitney (2009) stated that using authentic materials can increase the learners' motivation and develop their attitudes positively to learn the target language.

The results show that the available reading comprehension activities don't introduce real life texts that serve real life purposes. The selected textbook (FHFSA) lacks reading comprehension texts that help learners to deal with familiar issues in their lives. Usually, authentic materials discuss topics drawn from the real life. However, using authentic materials like, an article in a newspaper, as reading comprehension texts can be quite challenging for EFL learners because of the cultural gap between EFL learners and the culture of the target language. Moreover, the complexity of the texts and the used vocabulary can cause difficulties not only for EFL learners but also native speakers. Therefore, it is important to use real life texts which are the modified version of the original texts provided in authentic materials. These modified texts can be called authentic, MacDonald, Badger \& Dasli (2006) stated that texts can be called authentic if there is a resemblance between the texts used for practice in the classroom and forms of texts used in the real world. Fei \& Yu-feng (2008) stressed on selecting authentic texts that suit the learners' language level because texts of difficult lexical and structures make learners unmotivated to practice reading such texts. Therefore, it is important to design reading activities that introduce authentic texts that learners feel connected to and allow them to use their prior personal experiences to express their opinions and thoughts using the authentic language.

A significant result shows that the available authentic activities in the selected textbook (FHFSA) don't respond to the learners' individual needs. This is one of the drawbacks of authentic activities as they neglect the individual differences among learners which may cause difficulties for some learners in EFL learning. Authentic activities provide authentic language practices in authentic contexts where the use of language skills is integrated. This can be challenging for learners with lower level who have weaknesses in some of their language skills. EFL Learners' individual needs should be taken into the syllabus designers' account in the development process of the current textbook to modify these activities to respond to the learners' individual differences in learning the target language. Day (2003) stated that authentic activities can cause some problems to low level learners due to their complexity. Hwang (2005) suggested that authentic tasks should not be challenging to learners with lower level. 
An important result shows the efficiency of the available authentic activities in the selected textbook (FHFSA) as they help EFL learners to integrate into the real world as they provide practices of the target language that is used for communication in real life. Tatsuki (2006) stated that the real life is in the outside world and should be brought into the classroom through authentic tasks. These activities enable EFL learners to experience different situations and practice how to deal with such situations using authentic language as communication medium. This refers to the authenticity of the textbook activities as they present practices of integrated language skills in authentic contexts which prepare learners to react properly and communicate with multinational people they meet in real life using the target language.

\section{Conclusion}

This study investigates the extent that $1^{\text {st }}$ secondary English textbook of the new series (Flying High for Saudi Arabialevel -1), and focuses on the material authenticity. The results of the analysis process show that the selected textbook represented in its objectives, content and activities focus to a moderate extent on using authentic materials that can provide practices of the target language as it is used by native speakers in its actual contexts. The available materials can develop the learners' communicative skills and prepare EFL learners for the future uses of the target language in real life. However, the results reveal that the provided materials are beyond the learners' level, don't respond to the learners' individual needs which can cause difficulties for the learners and present real life reading texts at poor extent. Therefore, this study suggests some needed adjustments that can be beneficial for Saudi syllabus designers in the development process of the selected textbook. These suggestions recommend modifying the available materials to be more accessible for all the learners i.e. materials that match the learners' proficiency level and respond to their individual needs to facilitate language learning and motivate EFL learners to learn the target language.

\subsection{Suggestions \& Recommendations}

The obtained findings of this study reveal the necessity of making some needed adjustments to the authentic materials used in the current English textbook (FHFSA), that is taught in secondary schools. Therefore, the following recommendations are drawn from the significant results of this study that should be taken into the syllabus designers' considerations in the development process of this textbook:

First, the nature of the used authentic materials is considered quite challenging for the learners. The results show the necessity of creating materials that can simplify language learning i.e. to adapt the selected materials to learners' proficiency level. The policy makers in the Ministry of Education in Saudi Arabia always put the learners as their priority. Therefore, syllabus designers should design a modified version of the original materials that are produced by native speakers to facilitate communication and comprehension of the target language presented in these materials.

Second, the results reveal the necessity to select authentic materials that respond to the learners' individual needs. Since EFL classes in Saudi schools are mixed level classes, syllabus designers should work on identifying the needs of the learners and taking into accounts the individual differences among learners to select authentic materials that lead to develop the learners' abilities and overcome the difficulties that they face while learning the target language. Designers should look for materials that stimulate learners to learn more and help them to grow and have positive attitude towards learning the target language.

Third, syllabus designers should select authentic texts that can be accessible to all the learners i.e. texts that are appropriate to the learners' age and interest and that can enrich their background knowledge through feeding their previous learning experiences with new concepts from real life.

Fourth, syllabus designers should create reading comprehension activities that introduce real life texts that invest the learners' direct experiences i.e. providing opportunities for learners to share their own experiences in real life and express them using the target language like expressing one of their trips or weekend plans and share their indirect experiences like a stories they read in a book or listen to in a radio/T.V.

Fifth, syllabus designers should invest the current events through using authentic materials that can support learners with up to-date knowledge that make learners be aware and more involved of the world they live in.

Sixth, there should be more emphasis on language authenticity that is presented through the selected materials in the textbook i.e. the selected materials should offer to the learners a real exposure to the target language that is used in the real world outside their classrooms i.e. learners should be exposed to the phrases, expressions and idioms that are commonly used by native speakers.

\subsection{Limitations}

Certain limitations are anticipated in this study that may affect its credibility and the quality of the achieved results accordingly. These limitations are:

1. The collected responses from the participants in the analysis process can be subjective and may not represent the real perception of the teachers towards the used materials in the selected textbook.

2. To confirm that the collected data represents the perceptions of the majority of EFL teachers all over Saudi Arabia, a lot of participants working in secondary schools located in all Saudi regions should participate in the analysis process. However, covering all the areas of Saudi Arabia cannot be accomplished in a short period of time.

3. The Statistics \& Data Collection Center in the Ministry of Education does not provide a precise statistic of the total number of English teachers teaching $1^{\text {st }}$ secondary grade in Riyadh city, It only provides the total number of all English teachers working in secondary schools in Riyadh city. That means the actual population of this study can only be estimated from the total number of all English teachers working in secondary schools in Riyadh city. 


\section{References}

Allwright, R. L. (1981). What do we want teaching materials for? ELT Journal 36.(1), 5-18.

Amrani, F. (2011). The process of evaluation: A publisher's view. In B. Tomlinson (ed.), 267-295.

Apple, M. (1992). The text and cultural politics. Educational Researcher, 21(4),11.

Bacon, S. M. \& M. D. Finneman (1990). A study of the attitudes, motives and strategies of university foreign language students and their disposition to authentic oral and written input. The Modern Language Journal, 74 (4), $459-473$.

Berardo, S. (2006). The Use of authentic materials in the teaching of reading. The Reading Matrix, 6(2). 60-69.

British Council (2008). Teaching English: Course books. London.

Breen, M. (1985). Authenticity in the language classroom. Applied Linguistics 6(1), 60-70.

Dat, B. (2006). Breaking stereotypes in coursebooks. In J. Mukundan (ed.), 70-83.

Day, R. (2003). Authenticity in the design and development of materials. In W. A. Renandya (ed.),1-11.

Dendrinos, R. (1992). The EFL textbook and ideology. Athens: Grivas Publications, 31(1), 30-37

Duquette, G., Dunnett, S., \& Papalia, A. (1989). The effect of authentic materials in acquiring a second language. Canadian Modern Language Review, 43(479), 492

Ellis, R. (1999). Input based approaches to teaching grammar: A review of classroom oriented research. Annual Review of Applied Linguistics, 19(64),80.

Fei, L. \& Yu-feng. J. (2008). Application of authentic materials in extensive reading class in Chinese universities. USChina foreign language, 6(3).11-14.

Gilmore, A. (2004). A Comparison of textbook and authentic interactions. ELT Journal, 58(4).363-374.

Gilmore, A. (2007). Authentic materials and authenticity in foreign language learning. Language Teaching, 40 (97),118.

Gray, F. (2002). The global coursebook in English language teaching. In D. Block \& D. Cameron (eds.), Globalization and Language Teaching. London: Routledge, 151-166.

Guariento, W., \& Morley, J. (2001). Text and task authenticity in the EFL Classroom. ELT Journal, 55(4), $347-353$.

Horwitz, E. (2008). Becoming a Language Teacher: a Practical Guide to Second Language Learning and Teaching. Boston: Pearson Education. 19(22),26.

Hutchinson, T. \& E. Torres (1994). The textbook as agent of change. ELT Journal,48(4), 315-328.

Hwang, C. (2005). Effective EFL education through popular authentic materials. Asian EFL Journal.7(1).90-101.

Khinkar, W. (2000). Identifying the most important problems of English language curriculum for the first grade secondary from the viewpoint of the female teachers in Taif. Unpublished Master Thesis, College of Education, Umm Al-Qura University, Makkah.

Kilickaya. F. (2004). Authentic materials and cultural content in EFL classrooms. The Internet TESL Journal, $10(7), 31$. Krippendorff, K. (1980) Content analysis: an introduction to its methodology. Beverly Hills, CA: Sage.

Littlejohn, A. (1992). Why are ELT Materials the way they are? Unpublished Ph.D. thesis. Lancaster University.

Luke, C., S. de Castell \& A. Luke (1989). Beyond criticism: The authority of the school textbook. In S. de Castell, A. Luke \& C. Luke (eds.), Language, authority and criticism: Readings on the school textbook. London: Falmer Press, 81(2) 245-260.

MacDonald, M. N.\& Badger, R. Dasli, M. (2006). Authenticity, culture and language learning. Language and Intercultural Communication,6(3), 250-26.

Mahib ur Rahman, M. \& Alhaisoni, E. (2013). Teaching English in Saudi Arabia: Prospects and Challenges. Academic Research International,4(1),13.

Almazloum, M. and Qeshta, A. (2009). Evaluating the content of English for Palestine; grade ten textbook in the light of the standards for foreign language learning. Journal of Human Sciences, 43(7), 42-95.

McGarry, D. (1995). Learner autonomy 4: The role of authentic texts. Dublin: Authentic Language Learning Resources Ltd.

Mishan, F. (2005). Designing authenticity into language learning materials. Bristol: Intellect Books.

Mousavi, S. (2012). The effect of authentic versus non-authentic aural materials on EFL Learners' Listening Comprehension. English Language and Literature Studies.2(1),24-26.

Mukundan, J. (ed.) (2009a). Readings on ELT materials III. Petaling Jaya: Pearson Malaysia.

Nunan, D. (1999). Second language teaching and learning. Boston, MA: Heinle and Heinle.

Nuttall, C. (1996). Teaching reading skills in a foreign language. Oxford: Heinemann.

O’Neil, R. O. (1982). Why use textbooks? ELT Journal, 36(2), 104-111.

Prabhu, N. S. (1989). Materials as support: Materials as constraint. Guidelines, 11(66), 74.

Prodromou, L. (1992). What culture? Which culture?. ELT Journal ,46(1), 39-50.

Rilling, S. \& M. Dantas-Whitney (eds.) (2009). Authenticity in the language classroom and beyond: Adult learners. Alexandria, $V A$ : TESOL.

Sandelowski, M. (2000). Focus on Research Methods Whatever Happened to Qualitative Description? Research in Nursing \& Health, 334(340), 335-335. 
Shomoossi, N. \& Ketabi, S. (2007). A critical look at the concept of authenticity. National University of Singapore, Centre for Language Studies. Electronic Journal of Foreign Language Teaching,4(1), 149-155.

Shrum, J. L. \& Glisan, E. W. (2000). Teacher's Handbook: Contextualized Language Instruction. Boston: Heinle \& Heinle.

Alshumaimeri, Y. (2001). Saudi students' perceptions of their textbook: English for Saudi Arabia, (EFSA), Secondary Year One. University of Leeds, School of Education.

Alshumaimeri, Y. (2003). A study of classroom exposure to oral pedagogic tasks in relation to the motivation and performance of Saudi secondary learners of English in a context of potential curriculum reform. Unpublished Ph.D. Thesis, University of Leeds, Leeds.

Spelleri, M. (2002). From lessons to life: Authentic materials bridge the gap. ESL Magazine.

Tatsuki, D. (2006). What is Authenticity? The Language Teacher,16(5),17-21.

Thornbury, S. \& L. Meddings (2001). Coursebooks: The roaring in the chimney. Modern English Teacher 10(3), 11-13.

Tomlinson, B. (2012) Materials development for language learning and teaching. Cambridge University Press, 45(2), $143-179$.

Tomlinson, B. (2010b). What do teachers think about EFL coursebook?. Modern English Teacher, 19.(4), 5-9.

Tomlinson, B. (2001). Materials development. In Carter, R. \& Nunan, D. (Eds). The Cambridge guide to teaching English to speakers of other languages. Cambridge: Cambridge University Press.

Trabelsi, S. (2010). Developing and trialling authentic materials for business English students at a Tunisian university. In B. Tomlinson \& H. Masuhara (eds.), 103-120.

Van Lier, L. (1996). Interaction in the language curriculum: Awareness, autonomy and authenticity. Harlow, UK: Longman.

Velazquez, A. (2007). The use of authentic texts in the k-12 spanish program. Annual Research Forum,8(5), 133-138.

Wajnryb, R. (1996). Death, taxes and jeopardy: Systematic omissions in EFL texts, or life was never meant to be an adjacency pair. 9th Educational Conference, Sydney.

Widdowson, H. G. (1978). Teaching language as communication. Oxford: Oxford University Press.

Widdowson, H. G. (1984). Authentic versus purposeful activities. Council of Languages Association Conference,

Widdowson, H. G. (2000). On the limitations of linguistics applied. Applied Linguistics, 21(1), 3-25.

Wilkinson, D. \& Birmingham, P. (2003). Using research instruments: A guide for researchers. RoutledgeFalmer.

Wong, V., P. Kwok \& N. Choi (1995). The use of authentic materials at tertiary level. ELT Journal ,49(4),318-322.

Zohoorian, Z. \& Baghban,V. (2011). The Effectiveness of Using Authentic Materials in ESP

Courses. Islamic Azad University of Mashhad. English for Specific Purposes World,10(31), 56-58.

Alzuhairi, R. (2008). Reasons of the Low-level Achievement of Intermediate School Students in Learning English from the Viewpoint of Academics, Teachers and Supervisors in Makkah and Taif. Unpublished Master Thesis, College of Education, Umm Al-Qura University, Makkah. 